\title{
Eucypris fontana (Graf, 1931) (Crustacea, Ostracoda) in permanent environments of Patagonia Argentina: a geometric morphometric approach
}

\author{
Lorena Y. Ramos ${ }^{1 *}$, Marta Alperin ${ }^{2}$, A. Patricia Pérez ${ }^{3}$, Corina A. Coviaga ${ }^{1}$, Antje Schwalb \\ and Gabriela C. Cusminsky ${ }^{1}$ \\ ${ }^{1}$ Instituto de Investigación en Biodiversidad y Medioambiente (INIBIOM-UNComahue), Quintral 1250, 8400 San Carlos de \\ Bariloche, Argentina \\ 2 Cátedra de Estadística, Facultad de Ciencias Naturales y Museo, Universidad Nacional de La Plata, Calle 64 N 3 (e/Diag. 113 y Bva. \\ 120), 1900 La Plata, Argentina \\ 3 Laboratoriode Fotobiología, Instituto de Investigación en Biodiversidad y Medioambiente (INIBIOM-CONICET-UNComahue), \\ Quintral 1250, 8400 San Carlos de Bariloche, Argentina \\ ${ }^{4}$ Institut für Geosysteme und Bioindikation (IGeo), Technische Universität Braunschweig, Langer Kamp 19c, D-38106 \\ Braunschweig, Germany
}

Received 19 June 2014; Accepted 5 February 2015

\begin{abstract}
Ostracods are microcrustaceans with a calcareous carapace, very useful as paleoenvironmental indicators. Eucypris fontana (Graf, 1931) is a non-marine ostracod species, distributed in southern Neotropics, commonly found in living bisexual populations as well as in quaternary sequences in Patagonia. Geometry morphometric analysis offers efficient and powerful techniques to quantify, describe and analyze shape and size variations. In this study, phenotypic changes in the carapace (size and shape) of $E$. fontana were analyzed using geometric morphometric methods. One hundred and two valves, including males and females from surface sediments of six permanent water bodies located in Patagonia, Argentina, were analyzed. Male and female valves are spread in the morphospace and sexual dimorphism in size and shape were no perceived. Valve size (centroid size) differed between environments; larger individual were correlated with higher $\mathrm{Mg}^{2+}$, $\mathrm{Ca}^{2+}, \mathrm{K}^{+}$concentrations and temperature and lower $\mathrm{pH}(\sim 9.1)$ of the host waters, whereas smaller specimens were associated with the opposite environmental extreme. The principal component analysis performed with Procrustes coordinates (shape) indicated a morphological gradient between elongated and rounded valves; major changes occurring on the dorsal margin, calcified inner lamella and in the position of the adductor muscles scars. Rounded carapaces were related whit higher $\mathrm{Ca}^{2+}$ and $\mathrm{Mg}^{2+}$ concentration and lower $\mathrm{pH}(\sim 8.6)$ environments, whereas elongated valves were associated with the opposite environmental extreme. These results highlight the importance of morphometric studies of E. fontana in ecological research and their potential use in paleoenvironmental studies in Patagonia and other regions where this taxon is found.
\end{abstract}

Key words: Ostracoda / Patagonia / geometric morphometry / environmental control / paleoenvironmental reconstruction

\section{Introduction}

Ostracods are small aquatic crustaceans characterized by a chitinous-calcareous bivalved carapace. The growth of Cypridoidean ostracods is represented by eight molts to reach adulthood. At each molt, the cuticle covering both the body and the valves is shed; this is followed by a rapid increase in size and subsequent calcification of a new valve

*Corresponding author: lorenayramos@gmail.com
(Meisch, 2000). The high capacity of valve fossilization, their extensive fossil record, and the close relationship between ostracods and their habitats, make them excellent proxies for paleoenvironmental studies. The shape and the ornamentation of the shell, together with structural elements (i.e. calcified inner lamella, muscle prints and selvage), are the few features available when working with fossils or with hard parts. The valves represent the interface between the organism and the environment and the components of the shells are taken directly from the 
host water after molting; therefore some morphological features and elements reflect, at least partially, environmental conditions at the time of the formation of the shell (Turpen and Angell, 1971; Van Harten, 1975; Kaesler and Lohmann, 1976; Benson, 1981; Carbonel et al., 1988; Mezquita et al., 1999; Boomer et al., 2003). Particularly, it has been shown that the environment can produce intraspecific variations with respect to the ornamentation, as well as the shape and size of the shell (Reyment et al., 1988; Carbonel et al., 1990; Frenzel and Boomer, 2005).

Although morphological studies have interested biologist for a long time, it was in the late 80s and early 90 s that they have a boost when new methodologies appeared; these new analysis' methodologies are broadly called "Geometric Morphometry" (Adams et al., 2004; Zelditch et al., 2004). Geometric morphometry compile landmarks (i.e. homologous biological points) and outline methods to describe, quantify and analyze the change in shape and size of the specimens (Rohlf, 1990). The application of geometric morphometric techniques in ostracods studies is useful for the morphological characterization of taxa, to solve taxonomic issues, to describe shape variations, and for the identification of relationships between changes in shape and the environment (Baltanás and Danielopol, 2011). Morphometric studies in extant ostracods and their implications for paleoecological interpretation of fossil assemblages have emerged over the last 30 years (Baltanás et al., 2003). There are several studies that apply landmark methods in ostracods (Kaesler and Foster, 1988; Reyment et al., 1988; Reyment, 1993, 1997; Reyment and Bookstein, 1993; Elewa, 2003). Most of the morphometric ostracods studies performed outline analysis utilizing Fourier Analysis or Linhart's B-spline algorithm because ostracods valves do not always provide enough landmarks, or landmarks easy to record (e.g. Baltanás and Geiger, 1998; Yin et al., 1999; Van der Meeren et al., 2010). In Patagonia, a key region of special interest to Quaternary paleoclimate research, Wrozyna et al. (2008) have carried out a preliminary study using geometric morphometric techniques. They analyzed the morphological variability of the genus Limnocythere Brady, 1868, providing relevant information for the taxonomy of the genus as well as for its use in paleoenvironmental reconstructions.

In this study, Eucypris fontana (Graf, 1931) morphological variability from lakes and ponds in Patagonia were analyzed using landmarks method. This species is described first as Eucypris sarci Daday (1902) from lacustrine sediment of Patagonia and later Graf (1931) described it as Cypris fontana from South Georgia. De Deckker (1981) re-described it as E. fontana from Signy Island and South Georgia, both in the sub-Antarctic, and finally, based on the three descriptions the species were synonymized by Martens and Behen (1994). Recently, Karanovic (2008), based on the asymmetry of the valves, included this species in the genus Riocypris (i.e. Riocypris fontana) Klie, 1935 where the selvage in the right valve is inwardly placed. At present, this issue is still under discussion and in this study we follow the taxonomy proposed by De Deckker (1981). Although De Deckker (1981) did not found males in their material, Cusminsky and Whatley (1996) and Cusminsky et al. (2005) recorded males in quaternary sequences as well as in surfaces sediments.

Eucypris fontana is distributed in southern Neotropics, and is frequently found in bisexual population from Patagonia (Cusminsky and Whatley, 1996; Cusminsky et al., 2005; Martens and Savatenalinton, 2011; RamónMercau et al., 2012). This widely distributed species is common in recent assemblages and in quaternary sequences and has been used in ecological and paleoenvironmental studies (Cusminsky and Whatley, 1996; Whatley and Cusminsky, 1999, 2000; Schwalb et al., 2002; Markgraf et al., 2003; Cusminsky et al., 2005, 2011; Ramón-Mercau et al., 2012). Eucypris fontana has been recorded in ephemeral as well as in permanent environments, but it reaches its maximum abundance in permanent lakes (Markgraf et al., 2003; Cusminsky et al., 2005, 2011). It is a limnetic to mesohaline species, inhabiting waters with a wide range of solute composition and salinity (i.e. $35 \mathrm{mg} . \mathrm{L}^{-1}$ to $23760 \mathrm{mg} . \mathrm{L}^{-1}$ total dissolved solids) (Schwalb et al., 2002; Cusminsky et al., 2005; Ramón-Mercau et al., 2012).

It is interesting to examine the variability of shell morphometric in different populations and analyze their relation with the environment in order to deepen the knowledge of the species shape variability, ecology and to improve their potential as proxies for paleoenvironmental studies. The objective of this work was to analyze the intraspecific phenotypic variations in the shell of E. fontana in permanent freshwater environments of Patagonia with different physical and chemical conditions of the host water.

\section{Materials and methods}

\section{Study area}

Samples from 35 freshwater environments in Argentinean Patagonia (Schwalb et al., 2002; Cusminsky et al., 2005) were reviewed. Seven sites had abundant adult valves of $E$. fontana $(n>3)$ to be analyzed in this study (Table 1). These sites are located on the Patagonian plateau, between the Andes and the Atlantic coast ( $41^{\circ} 30^{\prime}-$ $48^{\circ} 56^{\prime} \mathrm{S}$ and $68^{\circ} 36^{\prime}-71^{\circ} 22^{\prime} \mathrm{W}$; Fig. 1). The climate of the region is temperate-cold, with a mean annual temperature decreasing southward (i.e. $12^{\circ} \mathrm{C}$ at $\mathrm{S} 40^{\circ}$ and $6^{\circ} \mathrm{C}$ at $\mathrm{S} 48^{\circ}$ ). Precipitation is more abundant and concentrated during the winter months, with a mean annual precipitation of $200 \mathrm{~mm}$ increasing to $500 \mathrm{~mm}$ toward the West, in the Andean region. The vegetation is typical of the shrub steppe, consisting of grasses with patches of tall bushes in valley bottoms (Paruelo et al., 1998; Markgraf et al., 2003).

There is one site in Northern Patagonia, La Vertiente (LV), is situated in the central plateau of the Río Negro province. This small lagoon has an area of $0.3 \mathrm{~km}^{2}$. 


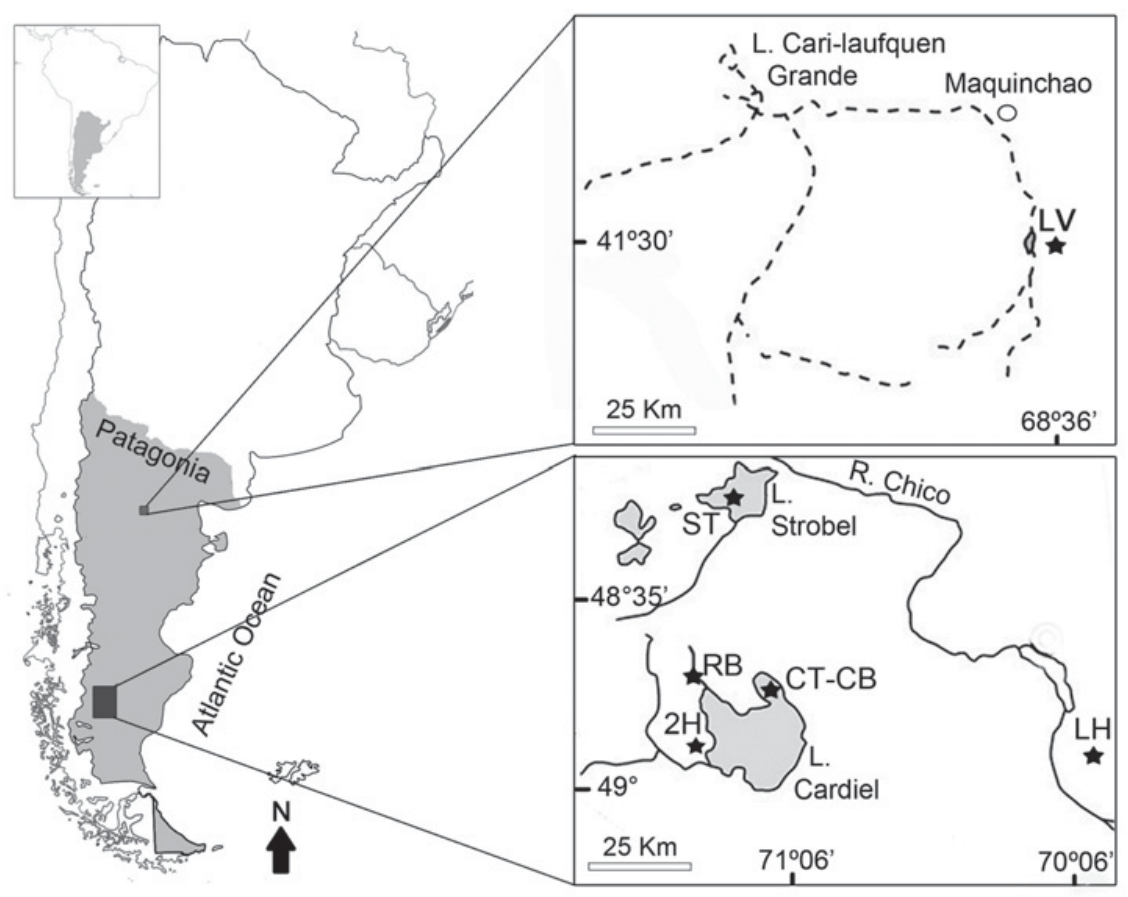

Fig. 1. Location of water bodies with Eucypris fontana. For site references see Table 1.

Table 1. Geographical coordinates, altitude, physical-chemical water features and number of left (LV) and right valves (RV) of each site.

\begin{tabular}{|c|c|c|c|c|c|c|c|c|c|c|c|}
\hline Site & $\begin{array}{l}\text { Location, } \\
\text { m.a.s.l. }\end{array}$ & $\mathrm{T}\left({ }^{\circ} \mathrm{C}\right)$ & $\mathrm{pH}$ & $\begin{array}{l}\text { Conductivity } \\
\left(\mu \mathrm{S} . \mathrm{cm}^{-1}\right)\end{array}$ & $\begin{array}{c}\mathrm{K}^{+} \\
\left(\mathrm{mEq} \cdot \mathrm{L}^{-1}\right)\end{array}$ & $\begin{array}{c}\mathrm{Ca}^{2+} \\
\left(\mathrm{mEq} . \mathrm{L}^{-1}\right)\end{array}$ & $\begin{array}{c}\mathrm{Mg}^{2+} \\
\left(\mathrm{mEq} . \mathrm{L}^{-1}\right)\end{array}$ & $\begin{array}{c}\mathrm{Na}^{+} \\
\left(\mathrm{mEq} \cdot \mathrm{L}^{-1}\right)\end{array}$ & LV & RV & Source \\
\hline $\mathrm{CB}$ & $\begin{array}{l}\text { S } 48^{\circ} 49^{\prime} \\
\text { W } 71^{\circ} 12^{\prime}, 276\end{array}$ & 6.6 & 9.6 & 1234 & 0.03 & 0.92 & 0.30 & 8.66 & $\begin{array}{l}\text { of } 8 \\
\text { ô } 1\end{array}$ & $\begin{array}{l}\text { o } 5 \\
\text { ô } 2\end{array}$ & This study \\
\hline $\mathrm{RB}$ & $\begin{array}{l}\text { S } 48^{\circ} 47^{\prime}, \\
\text { W } 71^{\circ} 21^{\prime}, 422,\end{array}$ & 10 & 9.1 & 1426 & 0.02 & 0.51 & 0.15 & 0.81 & $q 5$ & q 3 & This study \\
\hline ST & $\begin{array}{l}\text { S } 48^{\circ} 26^{\prime} \\
\text { W } 71^{\circ} 18^{\prime}, 735\end{array}$ & 11 & 8.6 & 2278 & 0.43 & 0.66 & 5.86 & 13.15 & $\begin{array}{l}\text { + } 4 \\
\text { o } 2\end{array}$ & $\begin{array}{l}\text { + } 5 \\
\text { 1 } 4\end{array}$ & $\begin{array}{l}\text { Cusminsky } \\
\text { et al. }(2005)\end{array}$ \\
\hline LH & $\begin{array}{l}\text { S } 48^{\circ} 56^{\prime} \\
\text { W } 70^{\circ} 05^{\prime}, 670\end{array}$ & 16 & 9.6 & 51278 & 5.11 & 1.65 & 11.04 & 378.83 & $\begin{array}{l}\text { o } 3 \\
\text { ô } 1\end{array}$ & 0 & $\begin{array}{l}\text { Cusminsky } \\
\text { et al. }(2005)\end{array}$ \\
\hline
\end{tabular}

Sites codes are as follows: LV, La Vertiente; 2H, Dos Hermanos; CT, Cardiel Transect; CB, Cardiel Bay; RB, Río Bayo; ST, Lake Strobel and LH, Laguna Honda.

The rest of the sites, Lake Strobel (ST), Lago Cardiel (two transects: CT-CB), Dos Hermanos (2H) lagoon, Río Bayo (RB) and Laguna Honda (LH) are situated in Southern Patagonia, in the Santa Cruz plateau. The surface of ST is about $97 \mathrm{~km}^{2}$ and has vegetated shores that provide habitat to a diverse array of birds and are also used for grazing sheep. Lago Cardiel, is a lake located in a tectonic depression, has a surface area of about $360 \mathrm{~km}^{2}$ with a maximum water depth of $76 \mathrm{~m}$. The lagoon $2 \mathrm{H}$, situated to the west of Lago Cardiel, is a small shallow lake, with a sandy bottom. Río Bayo is a river with highenergy fed by melting snow that originates in the Andes and flows into Northwest of Lago Cardiel. Finally, toward the East of Lago Cardiel is LH, a small lagoon of $0.78 \mathrm{~km}^{2}$ (Ariztegui et al., 2008).

The main environmental features are summarized in Table 1. Environmental data were obtained during 1998-2001 austral summer and in the case of LV lagoon, sampling was done during the austral spring of 2012. Conductivity $\left(\mu \mathrm{S} . \mathrm{cm}^{-1}\right), \mathrm{pH}$ and temperature $\left({ }^{\circ} \mathrm{C}\right)$ were measured in situ when the ostracods samples were collected. Ionic concentration $\left(\mathrm{K}^{+}, \mathrm{Na}^{+}, \mathrm{Ca}^{2+}\right.$ and $\left.\mathrm{Mg}^{2+}\right)$ was measured using the spectrometry technique of atomic absorbance (Perkin Elmer Analyst 100). 


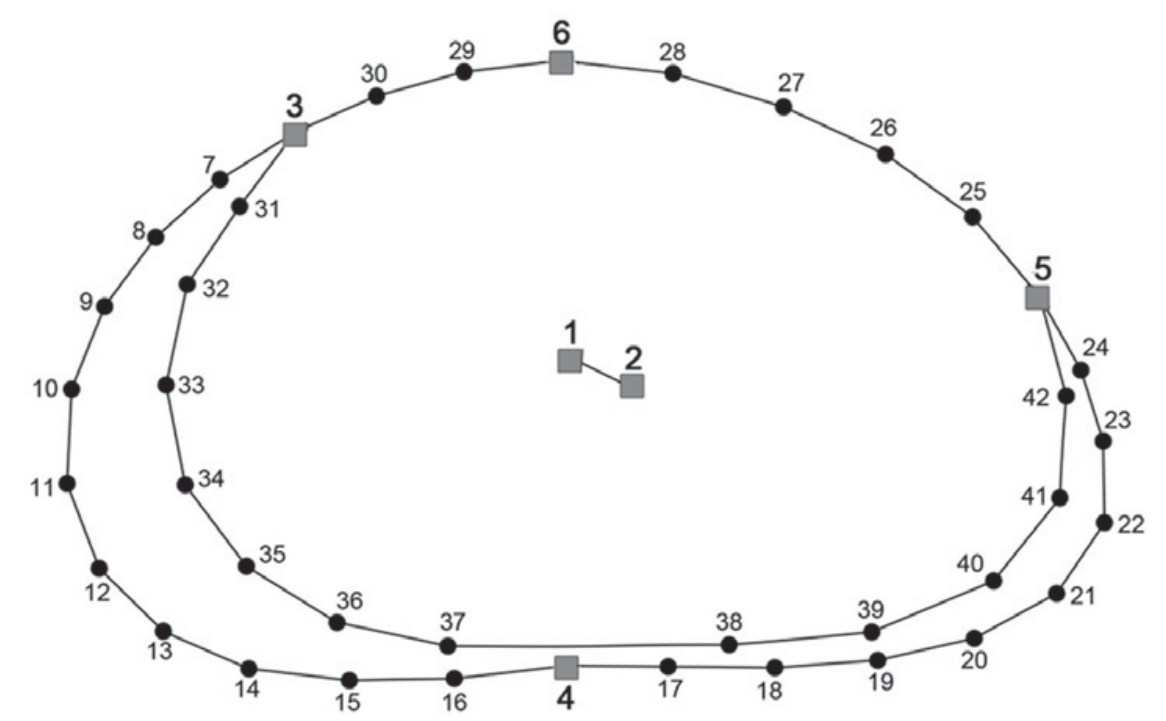

Fig. 2. Position of the six landmarks (gray squares) and 36 semilandmarks (black dots) on LV (external view) of Eucypris fontana. 1: center anterior adductor muscle scar, 2: center posterior adductor muscle scar, 3: antero-dorsal calcified inner lamella principle, 4: point of maximum concavity of the ventral margin, 5: end postero-dorsal of the calcified inner lamella, 6: point of maximum curvature of the dorsal margin.

\section{Morphometric and statistical analyses}

The adult valves retrieved from the samples were cleaned and mounted in external lateral view on glass slides to be observed under stereo-microscope. In all sites male and female individuals were found indicating sexual reproduction (RB males were not included because its valves were in poor condition). The males were identified by the presence of seminiferous tubules impressions (Meisch, 2000). Only unbroken clean valves without soft parts $\left(n=102, n_{\mathrm{LV}}=53, n_{\mathrm{RV}}=49\right.$, Table 1$)$ were photographed with a digital camera (Sony NSSC-DC50A), fitted to a stereo-microscope or a standard light microscope, and organized according to valve size.

The geometric morphometric analysis was performed using landmarks-based approach (Bookstein, 1996a, 1996b, 1997, 1998). This method not only allowed the study of variations in the external outline of valves, but also recorded shape changes on the margin of the calcified inner lamella and in the position of the adductor muscle scars. Size and shape changes were captured by analyzing variations in the position of landmarks and semilandmarks placed on the digital images of the valves. The Cartesian coordinates of a set of four anatomical landmarks (1, 2, 3 and 5), two mathematical (4 and 6) and 36 semilandmarks, 18 along ventral outline (7 to 24 ), six along dorsal outline (25 to 30$)$ and 12 along the margin of the inner lamella (31 to 42 ) were registered (Fig. 2) according to Dryden and Mardia (1998). The Cartesian coordinates of landmarks and semilandmarks were recorded using TpsDig software (Rohlf, 2001). Semilandmarks were converted to landmarks using the sliding method implemented in the TpsUtil and TpsRelw software (Rohlf, 2003, 2004) using the minimum bendingenergy criterion (Green, 1996; Bookstein, 1997).
Then, landmark configurations were superimposed using a Generalized Procrustes Analysis (Rohlf and Slice, 1990; Slice et al., 1996). The geometric morphometric approach allows separating size and shape, estimated by the centroid size (CS) and the Procrustes coordinates, respectively (Bookstein, 1991; Goodall, 1991; Dryden and Mardia, 1998).

The variance-covariance matrix of the Procrustes coordinates was used for principal component analysis (PCA). The PCA axes describe the maximum variation of shape in the morphospace (Rohlf and Archie, 1984; Hammer and Harper, 2006). Changes in valve shape were described according to Van Morkhoven (1962). Right and left valves have been analyzed separately because many Cypridoidea, including E. fontana, have bilateral asymmetry (Meisch, 2000). Sexual dimorphism variation in size (CS) was compared performing a $t$ test. Among-site variation in size was compared using analysis of variance (ANOVA) and the Tukey's post-hoc test was used for pairwise comparisons. Assumptions of normality and homoscedasticity were tested using the Kolmogorov-Smirnov and Levene statistic test, respectively. Additionally, discriminant analysis for classifying valves into different groups (i.e. male and females) was performed.

A multivariate regression analysis for each water body was conducted to evaluate the effects of size (CS used as the independent variable) on shape (Procrustes coordinates used as the dependent variables). The statistical significance of the model was calculated by a permutation test (10000 permutations) (Klingenberg, 2011).

Finally, the relation between changes in size and shape and the characteristics of the host water (temperature, $\mathrm{pH}$, conductivity and ionic concentration of $\mathrm{K}^{+}, \mathrm{Ca}^{2+}$, $\mathrm{Mg}^{2+}$ and $\mathrm{Na}^{+}$) were assessed. The non-parametric 


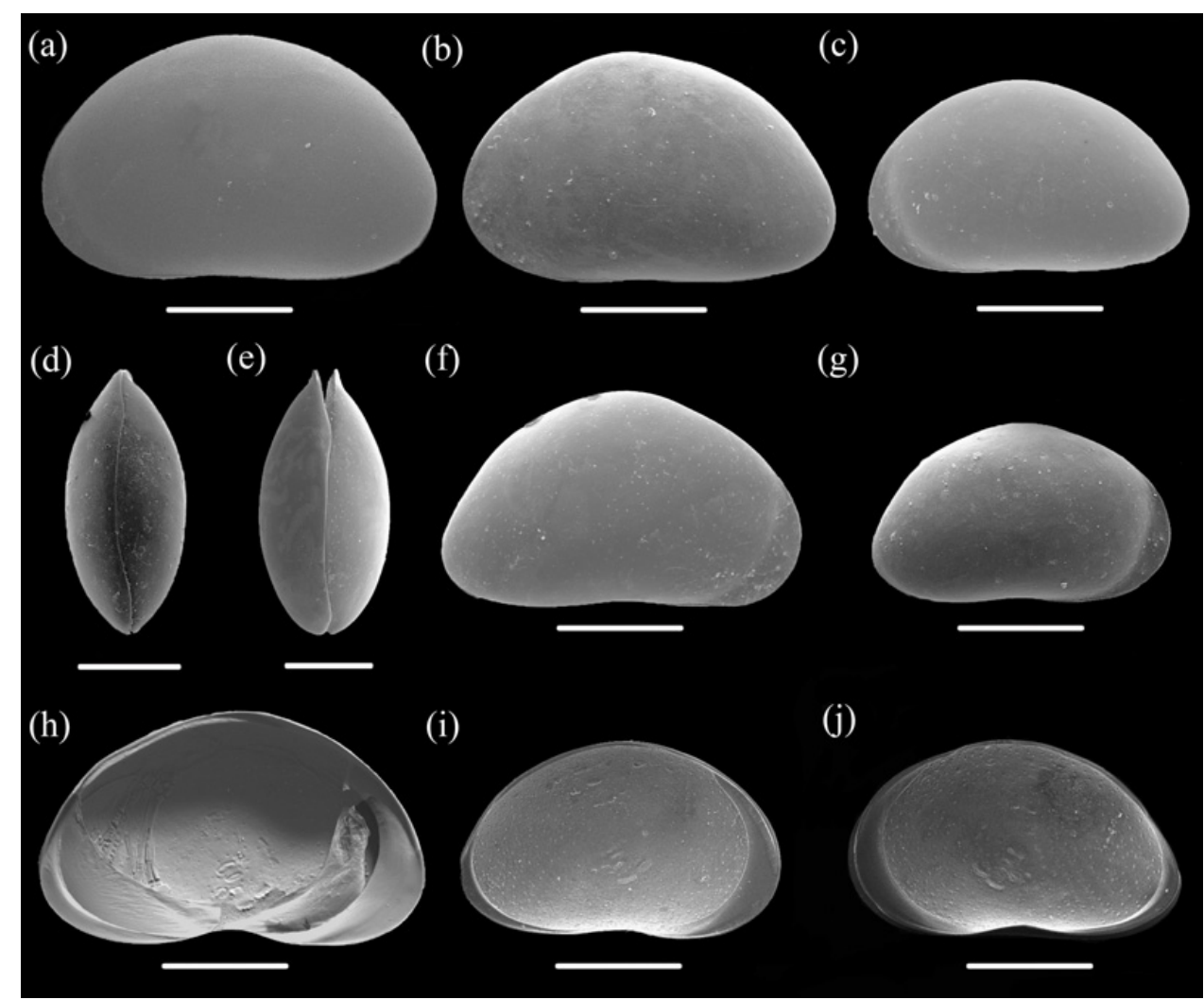

Fig. 3. SEM pictures of Eucypris fontana. External lateral view (a-c) of: (a) female LV from ST, rounded; (b) female LV from LH, rounded and (c) male LV from RB, elongated. Dorsal view (d and e) of: (d) carapace from $2 \mathrm{H}$, elongated and (e) carapace from LV, rounded. External lateral view (f and g) of: (f) male RV from LV, rounded and (g) male RV from $2 \mathrm{H}$, elongated. Internal lateral view $(\mathrm{h}-\mathrm{j})$ of: (h) male LV from LV, rounded, with remains of seminiferous tubules; (i) female LV from CT, elongated and (j) male RV from CT, elongated. Scales $=500 \mu \mathrm{m}$.

Spearman correlation coefficient $\left(R_{\mathrm{S}}\right)$ was calculated to estimate the relationship between $\mathrm{CS}$ and each environmental variable (Zar, 2010). Two-block partial least squares analysis (2B-PLS, Rohlf and Corti, 2000) was used to evaluate relationships between shape and environmental variables. This method reduces the dimensionality by the creation of a new linear combination of variables named singular axis, which maximizes the covariance between two groups of multivariate data. In this study one block corresponds to the shape and the other to the environmental variables. Although the correlation between the blocks may be low (null hypothesis of independence), it could exist a close relationship between some singulars axes and both blocks. The strength of the association is represented by the Pearson correlation coefficient $(r)$ and the significance by a permutation test (10000 permutations). A significant correlation coefficient in this analysis reveals that shape is significantly correlated to environmental traits. Prior to the analysis, the environmental variable matrix was standardized, in order to avoid parameters expressed in different units.

Geometric morphometrics and statistical analyses were performed using TPS software series (Rohlf, 2001, 2003, 2004), MorphoJ (v. 1.05b, Klingenberg, 2011) and Statistica (v. 10, StatSoft, Inc. 2010).

\section{Results}

\section{Sexual dimorphism}

A first analysis was performed to visualize and quantify morphological variability (i.e. size and shape) between male and female in both RVs and LVs of E. fontana (Fig. 3). Neither mean nor variance size (CS) differences between male and female for both valves were detected $\left(t_{\mathrm{RV}}=-1.44, P\right.$-level $=0.15 ; t_{\mathrm{LV}}=-0.59$, $P$-level $=0.56 ; \quad F_{\mathrm{RV}}=1.15, \quad P$-level $=0.43 ; \quad F_{\mathrm{LV}}=1.21$; $P$-level $=0.36)($ Fig. 4). In the PCA performed, the two principal components explain about $58 \%$ of total variance for both valves ( $\mathrm{LV}$ : $\mathrm{PC} 1=43.8 \%, \mathrm{PC} 2=13.4 \%$; $\mathrm{RV}$ : $\mathrm{PC} 1=40.8 \%, \mathrm{PC} 2=17.9 \%)$. The graphical results of the PCA (Fig. 5) show only one cluster in the morphospace were male and female valves overlap, indicating that no differences exist between male and female valves shape for $\mathrm{LV}$ and RV. The classification functions results of the discriminant analysis misclassified $50 \%$ of the 16 male LVs and $33 \%$ of the 37 female LVs and $35 \%$ of the 16 male RVs and $27 \%$ of the 33 female RVs. The fairly large proportions of incorrect classifications shows the difficulty of separating male to female valves using the shape. Therefore, on the basis of the present results (i.e. sexual dimorphism in size and shape are no perceived) male and 
(a)

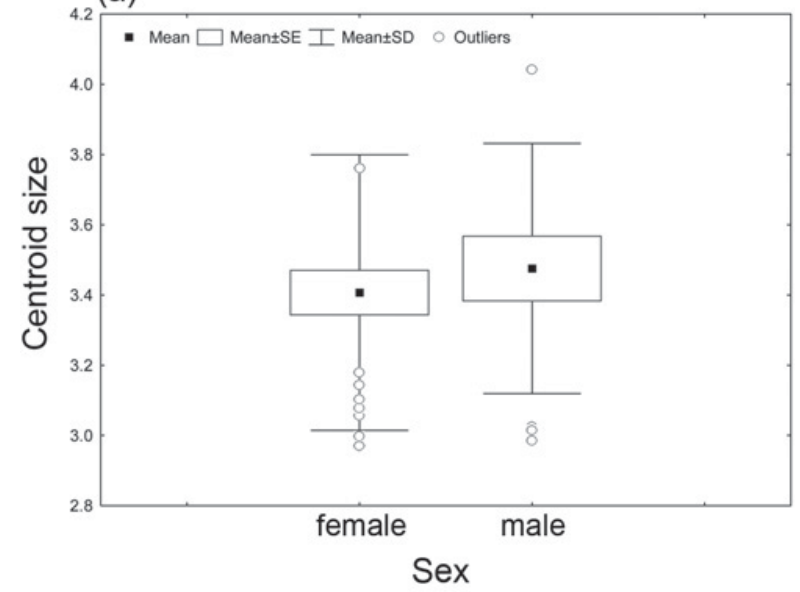

(b)

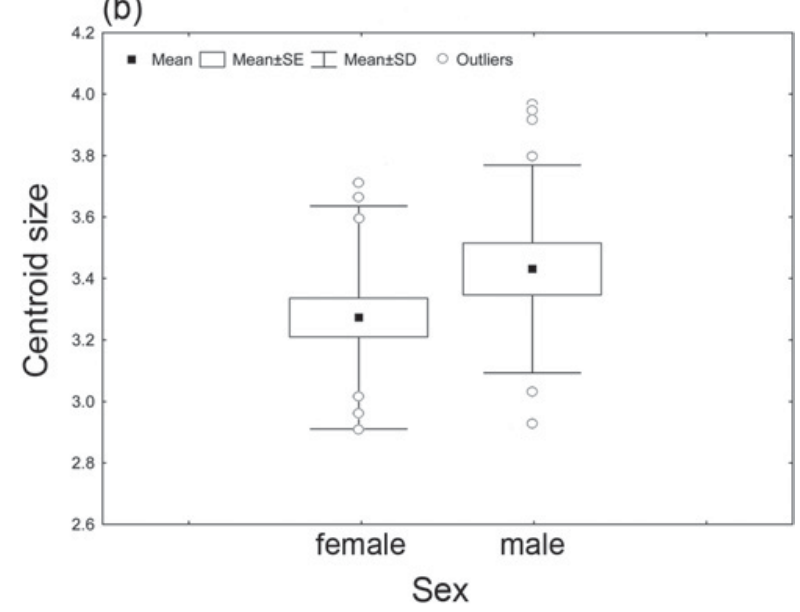

Fig. 4. Boxplot male and female valves vs. CS for (a) LVs and (b) RVs.

female valves were added in all subsequent analysis because they can be considered as belonging to a single cluster.

\section{Variations in size and shape}

The size of adult valves presents significant differences between sites (ANOVA, LVs $F_{6,0.05}=43.2 P<0.001$; $\left.\mathrm{RV} F_{5}, 0.05=42.5, P<0.001\right)$. The valves of $\mathrm{ST}, \mathrm{LV}$ and $\mathrm{LH}$ are longer than those of $2 \mathrm{H}$, Cardiel Transect (CT), Cardiel Bay (CB) and RB (Tukey's test, LV and RV $P<0.05$ ) (Fig. 6). Within-population high size variability was observed.

Figure 7(a), shows the sites PCA results for LVs. The first three principal components explain $69.2 \%$ of total variance $(\mathrm{PC} 1=43.8 \%, \mathrm{PC} 2=13.4 \%$ and $\mathrm{PC} 3=12.0 \%)$. PC1 accounts for the general shape, i.e. changes in dorsal margin and slight variations of antero-ventral area (external margin and calcified inner lamella). PC2 shows major changes in adductor muscle scars location, posteroventral margin and small changes in lamella development. Along PC1 a morphological gradient could be defined, in one extreme (semi-axe positive) are located "elongated" valves, and in the other extreme (semi-axe negative) (a)

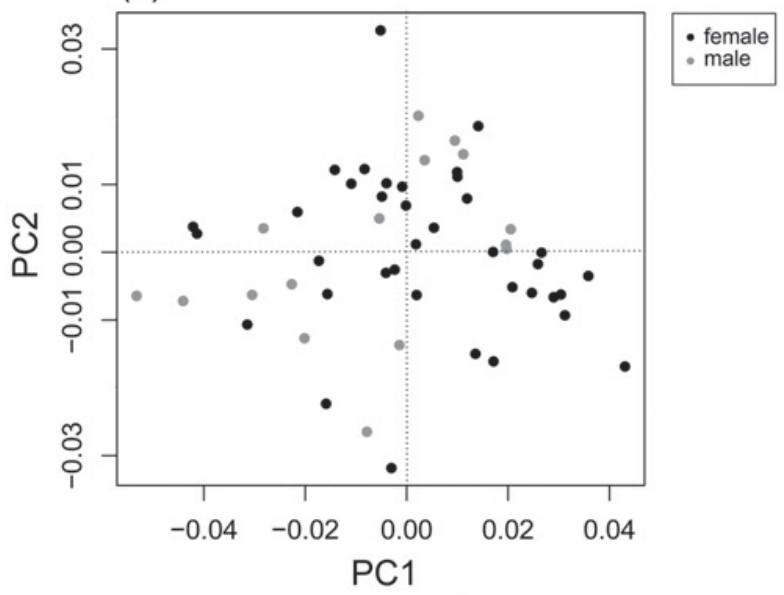

(b)

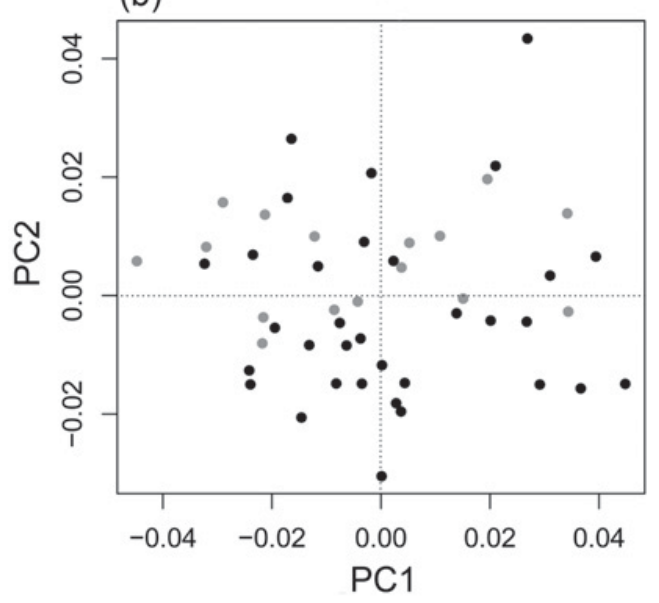

Fig. 5. Scatterplots of PC1 vs. PC2 male and female valves for (a) LVs and (b) RVs.

"rounded" valves occur. The elongated valves have the dorsal margin slightly rounded or flattened and the inner lamella poorly developed, whereas rounded valves have the dorsal margin markedly rounded or arched and more developed lamella, especially in the antero-ventral area. In the semi-axe positive of $\mathrm{PC} 2$, the valves have the postero-ventral margin slightly acuminate and the adductor muscle displaced toward the dorso-central area, whereas in the other extreme the valves have the posteroventral margin broadly rounded, and the adductor muscle situated toward the ventro-central area.

Left valves from $2 \mathrm{H}$ exhibit low shape variability, the valves are elongated, with the dorsal area flattened, the adductor muscle slightly displaced toward the dorsocentral area, and the lamella poorly developed ventrally. On the other hand, in $\mathrm{CB}, \mathrm{CT}$ and $\mathrm{RB}$, the valves exhibited higher variability; most of these shells are elongated, whereas LV, LH and ST present rounded valves with well develop of the inner lamella, especially in the anteroventral area.

For RVs (Fig. 7(b)), the first three principal components explained $74.6 \%$ of total variance $(\mathrm{PC} 1=40.8 \%$; $\mathrm{PC} 2=17.9 \%$ and $\mathrm{PC} 3=7.9 \%$ ). As in LVs PC1 showed 
(a)

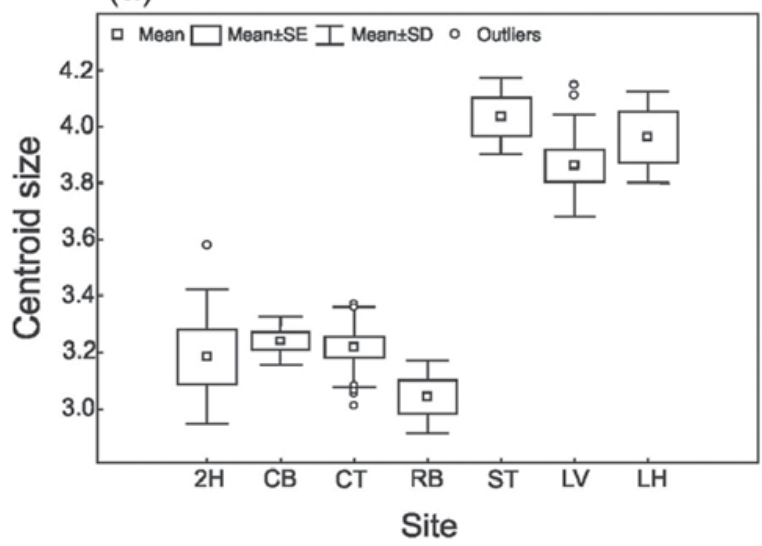

(b)

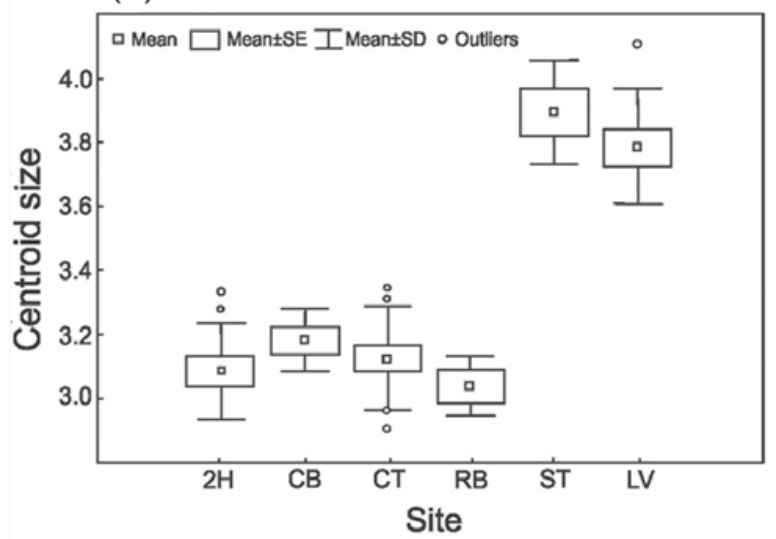

Fig. 6. Boxplot site vs. CS for (a) LVs and (b) RVs. For site references see Table 1.

changes in the shape; the variation lies in the dorsal and ventral margins, and in the location of adductor muscle scars; PC2 showed changes in the dorsal margin similar as $\mathrm{PC} 1$, and in the antero-ventral margin. The valves elongated with a dorsal flattened margin, and the adductor muscles toward the ventro-central area are placed in the positive PC1 semi-axe. The valves rounded with the dorsal margin markedly rounded, and the adductor muscle scars disposed toward the dorso-central area are located in the negative PC1 semi-axe. In reference to PC2, the valves rounded with dorsal margin markedly convex and anteroventral margin slightly rounded are located in the positive semi-axe; whereas the valves elongated with dorsal margin flattened antero-ventral margin broadly rounded lies in the opposite extreme.

The valves from $\mathrm{CB}$ have antero-ventral margin broadly rounded and the adductor muscle is located toward the dorso-central area. RB presents valves relatively elongated with the antero-ventral margin broadly rounded. The shape of valves collected from $2 \mathrm{H}$ and $\mathrm{CT}$ were particularly highly variable. Valves from LV show an antero-ventral margin slightly rounded and a lamella well developed especially in the antero-ventral area. ST valves have the same characteristics than LV, but have a more markedly convex dorsal margin. (a)

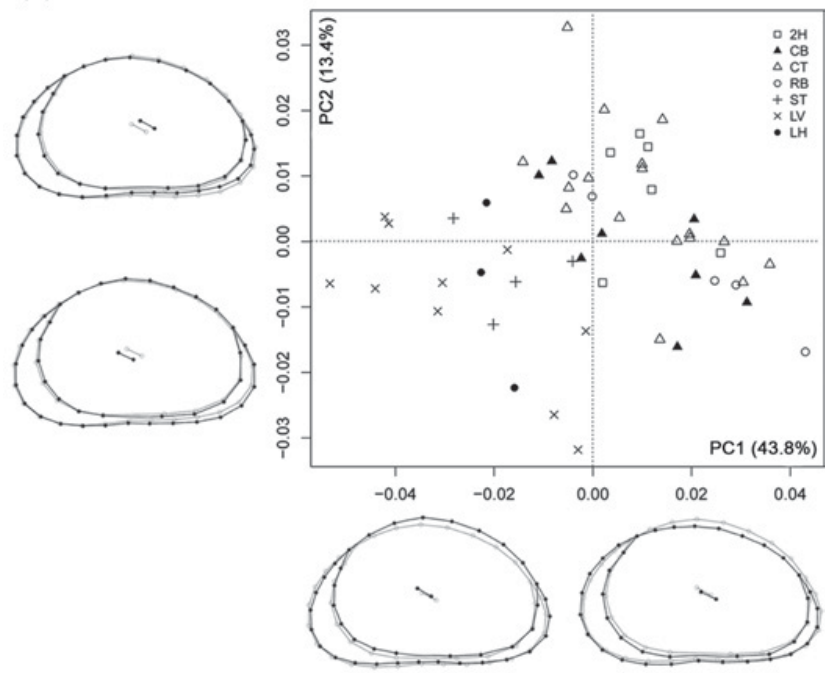

(b)
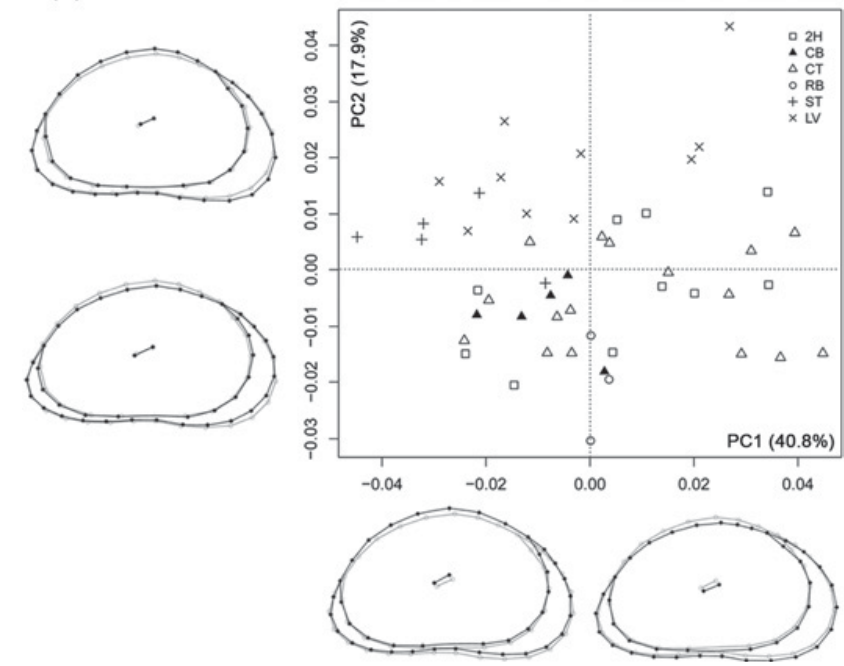

Fig. 7. Scatterplots of $\mathrm{PC} 1$ vs. PC2 for (a) LVs and (b) RVs. The valves diagrams, in external view, show shape changes associated with variation along each PC (black) compared to the average shape (gray). For site references see Table 1.

\section{The effect of size on shape}

Multivariate regressions analysis indicates that there is no size effect on shape, except for individuals from CT (permutation test with 10000 rounds, $P=0.002$ ). However, when the data set is analyzed as belonging to a single sample, the regressions results for LVs and RVs were significant, although the size explains only 27 and $19 \%$, respectively of the total shape variation (permutations test with 10000 rounds, $P<0.001$ ) (Table 2).

\section{Environment effects on size and shape}

The non-parametric Spearman correlation coefficient shows the association between LV and RV size and the environmental variables. LVs show positive correlation between CS with temperature, concentrations of $\mathrm{Mg}^{2+}$, 
Table 2. Multivariate regression of size on shape of left valves $(\mathrm{LV})$ and right valves (RV).

\begin{tabular}{lccccc}
\hline & \multicolumn{2}{c}{ LV } & & \multicolumn{2}{c}{ RV } \\
\cline { 2 - 3 } \cline { 5 - 6 } Sites & \% Pred. & $P$-value & & \% Pred. & $P$-value \\
\hline 2H & 28.66 & 0.183 & & 16.68 & 0.178 \\
CB & 25.80 & 0.113 & & 28.74 & 0.224 \\
CT & 20.97 & $0.002^{*}$ & & 25.91 & $0.002^{*}$ \\
RB & 15.63 & 0.495 & & 63.22 & 0.340 \\
ST & 40.31 & 0.288 & & 25.98 & 0.363 \\
LV & 13.41 & 0.276 & & 17.29 & 0.147 \\
LH & 55.71 & 0.329 & & - \\
All data & 26.62 & $<0.001^{*}$ & 19.44 & $<0.001^{*}$
\end{tabular}

$\%$ Pred., percent of shape variance explained by size.

*Significant at $P<0.05$. For site references see Table 1 .

$\mathrm{Ca}^{2+}, \mathrm{K}^{+}$and negative correlation with $\mathrm{pH}\left(R_{\mathrm{S}}\right.$ $P$-values $<0.05$ ) (Fig. 8). RVs present the same positive correlation than LVs (i.e. concentrations of $\mathrm{Mg}^{2+}, \mathrm{Ca}^{2+}$, $\mathrm{K}^{+}$), but negative correlation with $\mathrm{pH}$ add conductivity and $\mathrm{Na}^{+}$concentration $\left(R_{\mathrm{S}} P\right.$-values $\left.<0.05\right)($ Fig. 9).

The two-block partial least squares test reveals a significant association between shape and environmental variables $\left(\mathrm{RV}_{\mathrm{LV}}\right.$ coefficient $=0.3045, \mathrm{RV}_{\mathrm{RV}}$ coefficient $=$ $0.2929, P<0.0001)$. Table 3 displays the singular values and the correlation for the two-paired latent variables of the environmental block. These dimensions explain 90.4 and $7.4 \%$ for LVs, and 74.9 and $22.9 \%$ for RVs of the total squared covariance between the two sets of variables. The first dimension has its greatest positive loadings on the $\mathrm{Ca}^{2+}$ and $\mathrm{Mg}^{2+}$ and its greatest negative loading on the $\mathrm{pH}$ for both valves. For the second dimension the response is different in both valves, whereas the LVs have the greatest positive loading on the $\mathrm{Na}^{+}$and conductivity, the RVs have the greatest negative value on the temperature (Table 3).

The first morphological singular score axis and the first singular environmental score axis are significantly correlated for LVs and RVs (PLS $r=0.737 ; P<0.0001$ for LVs and PLS $r=0.707 ; P<0.0001$ for RVs). Rounded LVs and RVs were located in environments with higher concentrations of $\mathrm{Ca}^{2+}$ (i.e. $0.66-3.05 \mathrm{mEq} . \mathrm{L}^{-1}$ ) and $\mathrm{Mg}^{2+}$ (i.e. $4.2-11 \mathrm{mEq} . \mathrm{L}^{-1}$ for $\mathrm{LV}$ and $4.2-5.9 \mathrm{mEq} . \mathrm{L}^{-1}$ for $\mathrm{RV}$ ) and lesser $\mathrm{pH}$ (i.e. 8.6-9.6 for LVs and $\sim 8.6$ for RVs), whereas the elongated LVs and RVs were found at the opposite environmental extreme (i.e. $\mathrm{Ca}^{2+}$ between 0.51 and $0.92 \mathrm{mEq} \cdot \mathrm{L}^{-1} ; \mathrm{Mg}^{2+}$ between 0.15 and $1.81 \mathrm{mEq} . \mathrm{L}^{-1}$ and $\mathrm{pH} \sim 9.1$ ) (Figs. 10(a) and 11). The second morphological singular axis and the second environmental score axis are correlated for LVs (PLS $r=0.707 ; P<0.0001$ ) but not for RVs (PLS $r=0.442$; $P=0.1119)$. In the environment $(\mathrm{LH})$ with the highest conductivity $\left(51278 \mu \mathrm{S} . \mathrm{cm}^{-1}\right)$ and $\mathrm{Na}^{+}$concentration (378.83 mEq. $\mathrm{L}^{-1}$ ), LVs had dorsal margins more convex than those founded in environments with lesser conductivity (1426-6153 $\mu$ S.cm ${ }^{-1}$ ) and $\mathrm{Na}^{+}$concentrations (0.81-45.49 mEq.L ${ }^{-1}$ ) (Fig. 10(b)). These morphological changes along the second singular axis were less evident and the covariation was lower than for PLS1 $(P=0.07)$.

\section{Discussion}

\section{Sexual dimorphism}

Male and female valves are highly variable, there are rounded and elongated valves in both sexes (Fig. 3), but there is only one cluster in the morphospace and male and female valves are completely overlapped (Fig. 5). Sexual dimorphism is a very important aspect to consider in paleoenvironmental interpretations but is not always well expressed morphologically and this is the case for E. fontana (Boomer et al., 2003). Baltanás and Geiger (1998) explored Eucypris virens (Jurine, 1920) shape variability (using males and females) among different European and Chinese populations using elliptic Fourier coefficients. Their observation match partially with our results, males and females are quite similar in shape but differ in size (males E. virens are smaller than females). Results depicted in this work show that sexual dimorphism in E. fontana was not evident (i.e. size, outline, development of calcified inner lamella and position of the adductor muscle scar) using analysis of landmarks.

\section{Size variability and environmental effects}

The size of the adults $E$. fontana differs between sites (Figs. 3 and 6); this difference could be the result of environmental factors. In both LVs and RVs the size has a positive correlation between $\mathrm{Ca}^{2+}, \mathrm{Mg}^{2+}$ and $\mathrm{K}^{+}$concentrations and negative correlations with $\mathrm{pH}$ (Figs. 8 and 9). Specifically, the positive relation between size and concentrations of $\mathrm{Ca}^{+2}$ and $\mathrm{Mg}^{+2}$ could be related with the process of calcification of the valves since the chemical composition of the carapaces are in equilibrium with the chemical elements of their host waters and they build their new carapace by picking up chemical elements from the surrounding water during molting (Turpen and Angell, 1971; Mezquita et al., 1999). As for E. fontana, in the study of Yin et al. (1999), larger specimens from Limnocythere inopinata (Baird, 1843) inhabit a lake with waters with high calcium concentrations (Mondsee site in Table 1, Yin et al., 1999, loc. cit.), although this relationship was not statistically analyzed.

The effect of salinity on the ostracods body size has been widely reported; for $E$. fontana, the results show that conductivity and $\mathrm{Na}^{+}$concentration were negatively correlated with size in RVs, but not in LVs. Since the $\mathrm{Na}^{+}$concentration is intimately linked to the conductivity, the difference between both valves could be associated to the range of conductivity of the host waters, since LVs were found in the site with higher conductivity (51278 $\mu \mathrm{S} . \mathrm{cm}^{-1}$ ) and higher $\mathrm{Na}^{+}$concentrations (378.83 mEq.L ${ }^{-1}$ ) (Figs. 8 and 9). These results, negative correlation between valve length and solute concentrations, are agree with the relation described to E. virens, Cyprideis torosa (Jones, 1850), Mytilocypris henricae (Chapman, 1966), L. inopinata and some euryhaline ostracods 


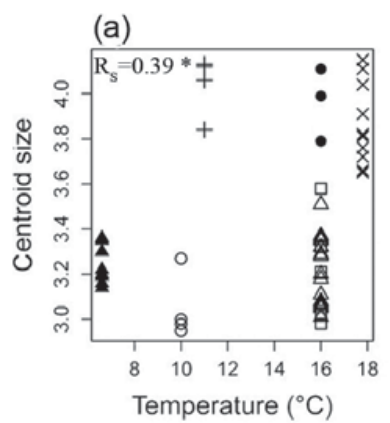

(e)

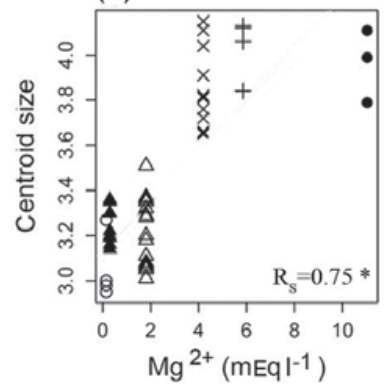

(b)

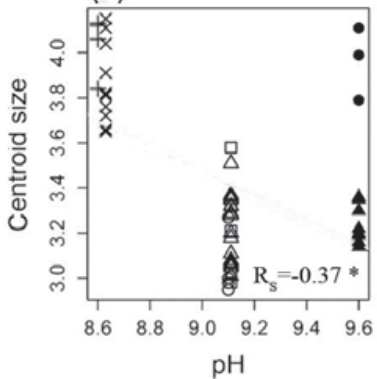

(c)

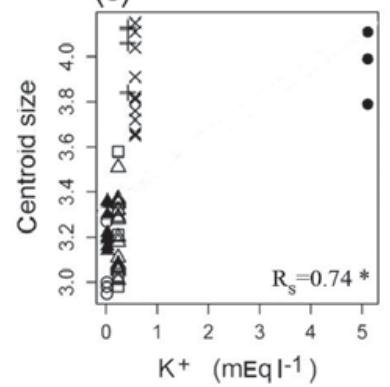

(d)

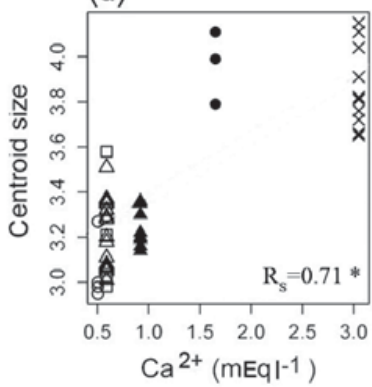

(g)
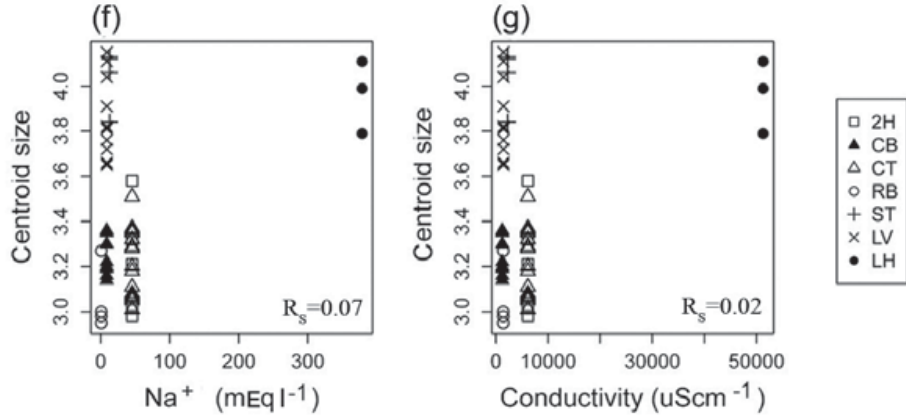

Fig. 8. Relationship between CS of Eucypris fontana LVs and (a) temperature, (b) $\mathrm{pH}$, (c) $\mathrm{K}^{+}$, (d) $\mathrm{Ca}^{2+}$, (e) $\mathrm{Mg}^{2+}$, (f) $\mathrm{Na}^{+}$and (g) conductivity at the different sites. ${ }^{*} R_{\mathrm{S}}$ indicate correlation significant at $\alpha=0.05$. For site references see Table 1.

(a)

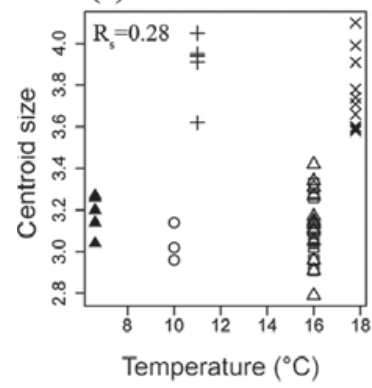

(e)

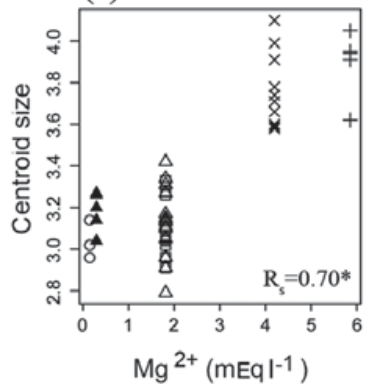

(b)

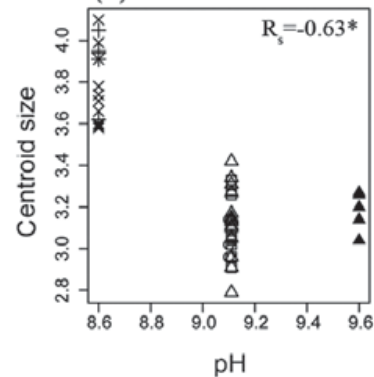

(c)

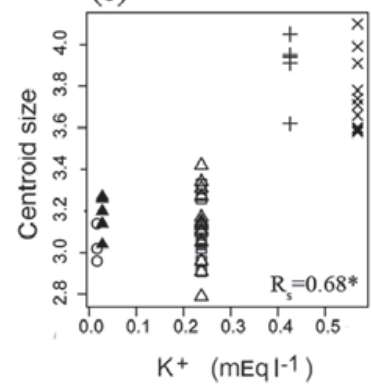

(d)

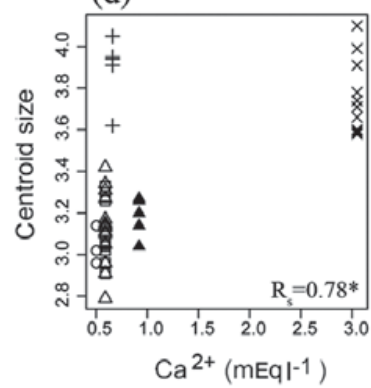

(g)
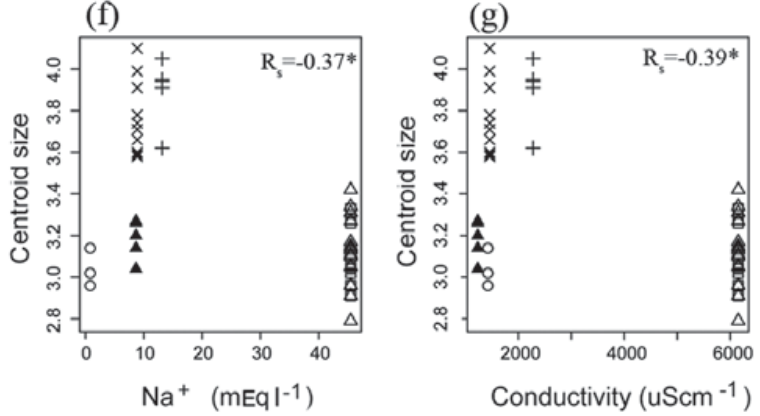

Fig. 9. Relationship between CS of Eucypris fontana RVs and (a) temperature, (b) $\mathrm{pH}$, (c) $\mathrm{K}^{+}$, (d) $\mathrm{Ca}^{2+}$, (e) $\mathrm{Mg}^{2+}$, (f) $\mathrm{Na}^{+}$and (g) conductivity at the different sites. ${ }^{*} R_{\mathrm{S}}$ indicate correlation significant at $\alpha=0.05$. For site references see Table 1 .

(Barker, 1963; Martens, 1985; Yin et al., 1999; Fernandes Martins et al., 2009; Van der Meeren et al., 2010).

Another factor that has a positive correlation with the size of the E. fontana valves is temperature (i.e. valves are bigger at higher temperature). The temperature is an important factor that influence the ostracods body size (Scheihing et al., 2011), nevertheless, the reverse association (lower temperature, larger body size) is a common rule in ectotherms, including ostracods, animals grow fast in warm environments, but they reach a relatively small adult size; and the opposite occurs in cool environments (Bergmann, 1847; Atkinson, 1994). On the geological scale, ostracods seem to follow this rule (Hunt and Roy, 2006) but laboratory experiments suggest that the rule can also apply to some species, e.g. E. virens (Martens, 1985; Baltanás and Geiger, 1998; Majoran et al., 2000; Mesquita-Joanes et al., 2012; Aguilar-Alberola and Mesquita-Joanes, 2014). Limnocythere inopinata natural 
Table 3. Results of a partial least-squares analysis of the covariation between the shape of Eucypris fontana and the environmental variables.

\begin{tabular}{|c|c|c|c|c|}
\hline & \multicolumn{2}{|c|}{ LV } & \multicolumn{2}{|c|}{ RV } \\
\hline & PLS1 & PLS2 & PLS1 & PLS2 \\
\hline Temperature $\left({ }^{\circ} \mathrm{C}\right)$ & 0.262 & -0.089 & 0.029 & -0.802 \\
\hline $\mathrm{pH}$ & -0.387 & 0.408 & -0.455 & 0.179 \\
\hline $\mathrm{Ca}^{2+}\left(\mathrm{mEq} \cdot \mathrm{L}^{-1}\right)$ & 0.608 & -0.347 & 0.425 & -0.334 \\
\hline $\mathrm{K}^{+}\left(\mathrm{mEq} \cdot \mathrm{L}^{-1}\right)$ & 0.310 & 0.398 & 0.085 & -0.058 \\
\hline $\mathrm{Mg}^{2+}\left(\mathrm{mEq} \cdot \mathrm{L}^{-1}\right)$ & 0.522 & 0.236 & 0.533 & -0.009 \\
\hline $\mathrm{Na}^{+}\left(\mathrm{mEq} \cdot \mathrm{L}^{-1}\right)$ & 0.147 & 0.497 & -0.389 & -0334 \\
\hline $\begin{array}{l}\text { Conductivity } \\
\left(\mu \mathrm{S} . \mathrm{cm}^{-1}\right)\end{array}$ & 0.147 & 0.495 & -0.401 & -0.312 \\
\hline Singular value & 0.026 & 0.007 & 0.022 & 0.012 \\
\hline$P$-value (perm.) & $<0.0001 *$ & 0.070 & $<0.0001^{*}$ & $0.0001 *$ \\
\hline$\%$ total covariation & 90.4 & 7.4 & 74.9 & 22.9 \\
\hline Correlation & 0.737 & 0.620 & 0.707 & 0.447 \\
\hline$P$-value (perm.) & $<0.0001^{*}$ & $<0.0001^{*}$ & $<0.0001^{*}$ & 0.1119 \\
\hline
\end{tabular}

$P$-value (perm.), probability of independence between variables after 10000 round of permutation test.

*Significant at $P<0.0001$.

and clonal populations respond in a different way (Yin et al., 1999), while for Limnocythere atacamae Brehm, 1935 the relationship between temperature and size is opposite to the rule (Scheihing et al., 2011). As well, studies of Heterocypris barbara (Gauthier and Brehm, 1928) testing the influence of multiple factors showed that the size of the valves is greater when the temperature, photoperiod and conductivity treatments are appropriately combined (Alcorlo et al., 1999). In addition, adult size ostracods could be affected by other factors as food availability, showing that the relation between E. fontana adult size and temperature may be very complex (Mezquita et al., 1999; Angilletta et al., 2004).

As mentioned before, high size variability withinpopulation of E. fontana was detected (Fig. 6). This adult size variability could be due to genetic diversity and environmental fluctuations (Baltanás and Geiger, 1998; Baltanás et al., 2000). Genotypic diversity is present in ostracods, inclusive in those reproducing through parthenogenesis (Adolfsson et al., 2010). Studies of E. virens and L. inopinata of natural and lab population's present spread size variability that has been attributed to genetic differences (Baltanás and Geiger, 1998; Yin et al., 1999; Fernandes Martins et al., 2009).

\section{Shape variability and environmental effects}

As it was stated above, a morphological shape gradient is recognized in both valves; at one extreme elongated valves, and at the other extreme, rounded valves. The elongated valves have the dorsal margin slightly rounded or flattened and the inner lamella poorly developed, whereas rounded valves have the dorsal margin markedly rounded or arched and a more developed lamella, especially in the antero-ventral area. Differences between morphotypes are more evident in the LVs than in the RVs (Figs. 3 and 7). (a)

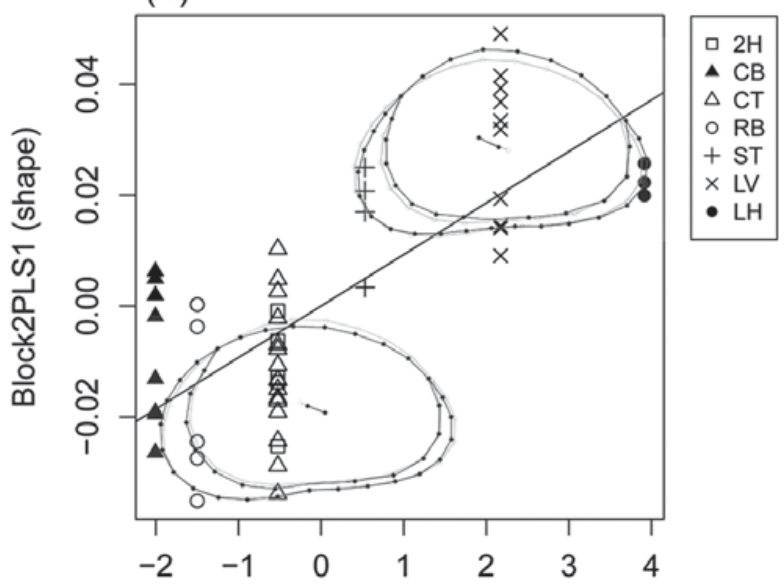

Block1PLS1 (environmental variables)

$<\mathrm{Ca}^{2+},<\mathrm{Mg}^{2+},>\mathrm{pH} \quad>\mathrm{Ca}^{2+},>\mathrm{Mg}^{2+},<\mathrm{pH}$

(b)

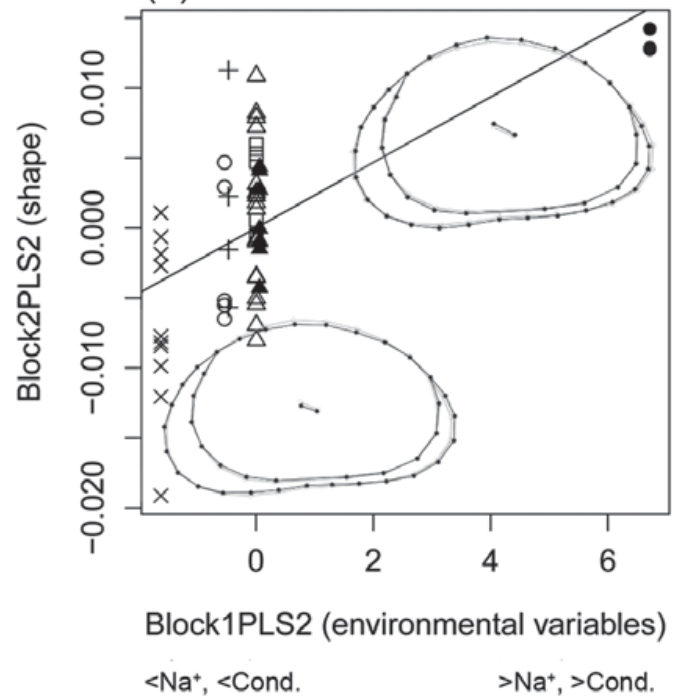

Fig. 10. (a) Left valves scatterplot of the first score of block 2 (shape variable) against the first score of block 1 (environmental variable), $r=0.737$. (b) Left valves scatterplot of the second score of block 2 (shape variable) against the second score of block 1 (environmental variable), $r=0.620$. The valves diagrams show changes associated with block 2 (black) compared to the average shape (gray). For site references see Table 1.

Elongated and rounded valves were associated with environmental conditions. The elongated morphotypes inhabit environments with lower concentration of $\mathrm{Ca}^{2+}$; $\mathrm{Mg}^{2+}$ and $\mathrm{pH} \sim 9.1$, whereas the rounded valves are found in environments with higher concentrations of $\mathrm{Ca}^{2+}$ and $\mathrm{Mg}^{2+}$ and lesser $\mathrm{pH}(\sim 8.6)$ (Figs. 10(a) and 11). In nonmarine ostracods, the shape of the valves is associated with ionic conditions, conductivity, temperature and $\mathrm{pH}$ (e.g. Baltanás and Geiger, 1998; Alcorlo et al., 1999), but there are contradictory signals about which is the most important factor. For example $H$. barbara shape changes relate mainly to temperature, although not exclusively 


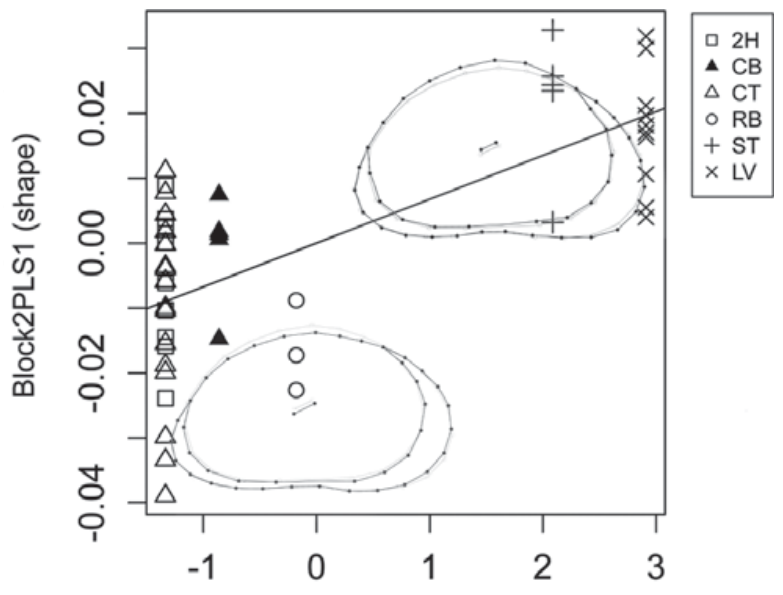

Block1PLS1 (environmental variables)

$$
<\mathrm{Ca}^{2+},<\mathrm{Mg}^{2+},>\mathrm{pH} \quad>\mathrm{Ca}^{2+},>\mathrm{Mg}^{2+},<\mathrm{pH}
$$

Fig. 11. Right valves scatterplot of the first score of block 2 (shape variable) against the first score of block 1 (environmental variable), $r=0.707$. The valves diagrams show changes associated with block 2 (black) compared to the average shape (gray). For site references see Table 1.

(Alcorlo et al., 1999) and for L. inopinata shape changes with the salinity and $\mathrm{pH}$ of the host water (Baltanás and Geiger, 1998; Roberts et al., 2002; Yin et al., 1999; Van der Meeren et al., 2010). In lab conditions the temperature has little effect on $E$. virens shape cultures but, in natural populations, morphological differences could be driven by environmental factors (Baltanás and Geiger, 1998; Baltanás et al., 2002).

As stated, E. fontana presents wide range of shape variability within-population (Fig. 7). Since for all population sexually reproducing high diversity genetics was expected, then phenotypic variations within-population can be genetically coded but with an environmental cued expression as proposed by Alcorlo et al. (1999). Other species also show greater shape variability in sexual and parthenogenetic populations (e.g. E. virens and $L$. inopinata) that might be explained by genetic and environmental factors (Baltanás and Geiger, 1998). Van der Meeren et al. (2010) observed that a greater shape variance of $L$. inopinata inhabiting highly fluctuating environments, responds to temperature, specific conductance and higher clonal diversity of populations. It would be interesting to conduct genetic studies of $E$. fontana to evaluate the genetic variability within and between populations from different sites.

\section{Size, shape and environmental effects}

In this study, E. fontana valves from different environments presented variations in size and shape. Results from multivariate regressions indicated that, with the exception of the CT population, shape variations were not correlated with size variations within each site (Table 2). However, in general, the larger valves are more rounded while the smaller valves are associated to more flattened or elongated valves. Note that the size differences are more evident than the shape differences (Fig. 3). These morphological responses seem to be driven not by one environmental factor alone but by a combination of factors (i.e. $\mathrm{pH}, \mathrm{Ca}^{+2}$ and $\mathrm{Mg}^{+2}$ concentrations) and also by genetic causes.

\section{Conclusions}

In this, the first study based on morphometric techniques in Patagonian aquatic environments, phenotypic variation (shape and size) of Eucypris fontana natural populations was documented in detail. Also, notwithstanding the limited data (i.e. 102 valves), the results strongly suggest that size and shape variations may be caused by environmental factors, particularly $\mathrm{Ca}^{+2}$ and $\mathrm{Mg}^{+2}$ concentrations and $\mathrm{pH}$ of the host water. However, it is not excluded that other abiotic and biotic factors may also have an effect on the morphometry of the valves (e.g. genetic variability, photoperiod, principal anionic concentration and food supply). Furthermore, it could be interesting to investigate morphometric variation in a broader environmental range e.g. including ephemeral lakes. The two morphotypes recognized (i.e. elongated and smaller vs. rounded and larger) of E. fontana could be useful for quaternary paleoenvironmental reconstructions, in particular, related to dissolved ion concentration $\left(\mathrm{Ca}^{+2}\right.$ and $\mathrm{Mg}^{+2}$ ) and $\mathrm{pH}$ of Patagonian lakes. Finally, this study highlights that the geometric morphometric add statistical analyses not only are effective tools to reveal small variations in E. fontana, but also to examine the relation between morphological patterns and ecological variables.

Acknowledgements. This study was funded by the National Agency for the Promotion of Science and Technology (ANPCyT), PICT 2010-0082 and the National Council of Science and Technology of Argentina (CONICET) PIP 00819 and 00021. This work is also a contribution to the Comahue National University (Project B166). We thank the Patagonian Lake Drilling Project PATO/PALATRA team members. We also appreciate Daniel Ariztegui's help with water chemistry data and Rolando González-José for his encouragement and suggestions about geometric morphometric analysis. Special thanks to very helpful anonymous reviewers.

\section{References}

Adams D.C., Rohlf F.J. and Slice D.E., 2004. Geometric morphometrics: ten years of progress following the 'revolution'. Ital. J. Zool., 71, 5-16.

Adolfsson S., Michalakis Y., Paczesniak D., Bode S.N.S., Butlin R.K., Lamatsch D.K., Martins M.J.F., Schmit O., Vandekerkhove J. and Jokela J., 2010. Evaluation of elevated ploidy and asexual reproduction as alternative explanations for geographic parthenogenesis in Eucypris virens ostracods. Evolution, 64, 986-997.

Aguilar-Alberola J. and Mesquita-Joanes F., 2014. Breaking the temperature-size rule, thermal effects on growth, 
development and fecundity of a crustacean from temporary waters. J. Therm. Biol., 42, 15-24.

Alcorlo P., Baltanás Á. and Arqueros L., 1999. Intra-clonal shape variability in the non-marine ostracod Heterocypris barbara (Crustacea, Ostracoda). Geosound-Yerbilimleri, 35, $1-11$.

Angilletta M.J., Steury T.D. and Sears M.W., 2004. Temperature, growth rate, and body size in ectotherms: fitting pieces of a life-history puzzle. Integr. Comp. Biol., 44, 498-509.

Ariztegui D., Anselmetti F.S., Gilli A. and Waldmann N., 2008. Late Pleistocene environmental change in Eastern Patagonia and Tierra del Fuego - a limnogeological approach. In: Rabassa J. (ed.), The Late Cenozoic of Patagonia and Tierra del Fuego, Elsevier, Amsterdam, 241-253.

Atkinson D., 1994. Temperature and organism size, a biological law for ectotherms? Adv. Ecol. Res., 25, 1-58.

Baltanás Á. and Danielopol D.L., 2011. Geometric morphometrics and its use in ostracod research: a short guide. Joannea Geol. Paläontol., 11, 235-272.

Baltanás Á. and Geiger W., 1998. Intraspecific morphological variability, morphometric of valve outlines. In: Martens K. (ed.), Sex and Parthenogenesis, Evolutionary Ecology of Reproductive Modes in Non-Marine Ostracoda (Crustacea), Backhuys Publishers, Leiden, 172-142.

Baltanás Á., Otero M., Arqueros L., Rossetti G. and Rossi V., 2000. Ontogenetic changes in the carapace shape of the nonmarine ostracod Eucypris virens (Jurine). Hydrobiologia, 419, 65-72.

Baltanás Á., Alcorlo P. and Danielopol D.L., 2002. Morphological disparity in populations with and without sexual reproduction, a case study in Eucypris virens (Crustacea, Ostracoda). Biol. J. Linn. Soc., 75, 9-19.

Baltanás Á., Brauneis W., Danielopol D.L. and Linhart J., 2003. Morphometric methods for applied ostracodology, tools for outline analysis of nonmarine ostracods. In: Park L.E. and Smith A.J. (eds.), Bridging the Gap, Trends in the Ostracod Biological and Geological Sciences, The Paleontological Society Papers, New Haven, 101-118.

Barker D., 1963. Size in relation to salinity in fossil and recent euryhaline ostracods. J. Mar. Biol. Ass., 43, 785-795.

Benson R.H., 1981. Form, function and architecture of ostracod shells. Annu. Rev. Earth Planet. Sci., 9, 59-80.

Bergmann C., 1847. Über die Verhältnisse der Wärmeökonomie der Thiere zu ihrer Grösse. Göttinger Studien, 3, 595-708.

Bookstein F.L., 1991. Morphometric Tools for Landmark Data: Geometry and Biology, Cambridge University Press, Cambridge, 435 p.

Bookstein F.L., 1996a. Biometrics, biomathematics and the morphometric synthesis. Bull. Math. Biol., 58, 313-365.

Bookstein F.L., 1996b. Combining the tools of geometric morphometrics. In: Marcus L.F., Corti M., Loy A., Naylor G.J.P. and Slice D.E. (eds.), Advances in Morphometrics, Nato ASI Series, Series A: Life Science, Plenum, New York, 131-152.

Bookstein F.L., 1997. Landmark methods for forms without landmarks: morphometrics of group differences in outline shape. Med. Image Anal., 1, 225-243.

Bookstein F.L., 1998. A hundred years of morphometrics. Acta Zool. Hung., 44, 7-59.
Boomer I., Horne D.J. and Slipper I.J., 2003. The use of ostracods in palaeoenvironmental studies, or what can you do with an ostracod shell? In: Park L.E. and Smith A.J. (eds.), Bridging the Gap, Trends in the Ostracod Biological and Geological Sciences, The Paleontological Society Papers, New Haven, 153-180.

Carbonel P., Colin J. and Danielopol D.L., 1988. Paleoecology of limnic ostracods, a review of some major topics. Palaeogeogr. Palaeoclimatol. Palaeoecol., 62, 413-461.

Carbonel P., Mourguiart P. and Peypouquet J.P., 1990. The external mechanisms responsible for morphological variability in Recent Ostracoda, seasonality and biotope situation. An example from Lake Titicaca. In: Whatley R. and Maybury C. (eds.), Ostracoda and Global Events. British Micropalaeontological Society Publication Series, Chapman and Hall, London, 331-340.

Cusminsky G.C. and Whatley R., 1996. Quaternary non-marine ostracods from lake beds in northern Patagonia. Rev. Esp. Paleontol., 11, 143-152.

Cusminsky G.C., Pérez P.A., Schwalb A. and Whatley R., 2005. Recent lacustrine ostracods from Patagonia, Argentina. Rev. Esp. Micropaletol., 37, 431-450.

Cusminsky G.C., Schwalb A., Pérez P.A., Pineda D., Viehberg F., Whatley R. and Anselmetti F.S., 2011. Late quaternary environmental changes in Patagonia as inferred from lacustrine fossil and extant ostracods. Biol. J. Linn. Soc., 103, 397-408.

Daday E.V., 1902. Mikroskopische -susswasserthiere aus Patagonien. Természetrajzi Füzetek, 25, 201-313.

De Deckker P., 1981. On Eucypris fontana. Stereo-Atlas of Ostracods Shells, 8, 87-92.

Dryden I.L. and Mardia K.V., 1998. Statistical Shape Analysis, John Wiley and Sons, Chichester, 172 p.

Elewa A.M.T., 2003. Morphometric studies on three ostracod species of the genus Digmocythere Mandelstam from the Middle Eocene of Egypt. Palaeontol. Electon., 6, $1-11$.

Fernandes Martins M.J.F., Vandekerkhove J., Mezquita F., Schmit O., Rueda J., Rossetti G. and Namiotko T., 2009. Dynamics of sexual and parthenogenetic populations of Eucypris virens (Crustacea: Ostracoda) in three temporary ponds. Hydrobiologia, 636, 219-232.

Frenzel P. and Boomer I., 2005. The use of ostracods from marginal marine, brackish waters as bioindicators of modern and quaternary environmental change. Palaeogeogr. Palaeoclimatol. Palaeoecol., 225, 68-92.

Goodall C., 1991. Procrustes methods in the statistical analysis of shape. J. R. Stat. Soc., B, 53, 285-339.

Graf H., 1931. Süsswasser Ostracoden aus Sudgeorgian. Zool. Anz., 93, 185-191.

Green W.D.K., 1996. The thin-plate spline and images with curving features. In: Mardia K.V., Gill C.A. and Dryden I.L. (eds.), Proceedings in Image Fusion and Shape Variability Techniques, Leeds University Press, Leeds, 79-87.

Hammer O. and Harper D., 2006. Paleontological Data Analysis, Blackwell, Oxford, 351 p.

Hunt G. and Roy R., 2006. Climate change, body size evolution and Cope's Rule in deep-sea ostracods. Proc. Natl. Acad. Sci. USA, 103, 1347-1352.

Kaesler R.L. and Foster D.W., 1988. Ontogeny of Bradleya normani (Brady), Shape analysis of landmarks. 
In: Hanai T. and Ikeya K. (eds.), Evolutionary Biology of Ostracoda, Elsevier Kodansha, Tokyo, 207-218.

Kaesler R.L. and Lohmann K.C., 1976. Phenotypic variation of populations of Krithe producta with environment. Abh. Verh. Naturwiss. Ver. Hamburg, (N/F), 18/19(Suppl.), 279-285.

Karanovic I., 2008. Three interesting Cyprididae (Ostracoda) from Western Australia. Rec. Aust. Mus., 24, 267-287.

Klingenberg C.P., 2011. MorphoJ, an integrated software package for geometric morphometrics. Mol. Ecol. Resour., 11, 353-357.

Majoran S., Agrenius S. and Kucera M., 2000. The effect of temperature on shell size and growth rate in Krithe praetexta praetexta (Sars). Hydrobiologia, 419, 141-148.

Markgraf V., Bradbury J.P., Schwalb A., Burns S.J., Stern C., Ariztegui D. and Maidana N., 2003. Holocene palaeoclimates of southern Patagonia, limnological and environmental history of Lago Cardiel, Argentina. The Holocene, 13, 581-591.

Martens K., 1985. Effects of temperature and salinity on postembryonic growth in Mytilocypris henricae (Chapman) (Crustacea, Ostracoda). J. Crustac. Biol., 5, 258-272.

Martens K. and Behen F., 1994. A checklist of the recent non-marine ostracods (Crustacea, Ostracoda) from the inland waters of South America and adjacent islands. Trav. Sci. Mus. Natl. Hist. Nat. Luxemb., 22, 84.

Martens K. and Savatenalinton S., 2011. A subjective checklist of the recent, free-living non-marine Ostracoda (Crustacea). Zootaxa, 2855, 1-79.

Meisch C., 2000. Freshwater Ostracoda of Western and Central Europe, Spektrum Akademischer Verlag, Heidelberg, 522 p.

Mezquita F., Roca J.R. and Wansard G., 1999. Moulting, survival and calcification, the effects of temperature and water chemistry on an ostracod crustacean (Herpetocypris intermedia) under experimental conditions. Arch. Hydrobiol., 146, 219-238.

Mesquita-Joanes F., Smith A.J. and Viehberg F.A., 2012. The ecology of Ostracoda across levels of biological organisation from individual to ecosystem: a review of recent developments and future potential. In: Horne D.J., Holmes J.A., Rodgriguez-Lazaro J. and Viehberg F.A. (eds.), Ostracoda, as Proxies for Quaternary Climate Change, Developments in Quaternary Science, Elsevier, Oxford, 15-35.

Paruelo J., Beltran A., Jobbágy E., Sala O. and Golluscio R., 1998. The climate of Patagonia, general patterns and controls on biotic. Ecol. Austral., 8, 85-101.

Ramón-Mercau J., Laprida C., Massaferro J., Rogora M., Tartari G. and Mainada N., 2012. Patagonian ostracods as indicators of climate related hydrological variables, implications for paleoenvironmental reconstructions in Southern South America. Hydrobiologia, 694, 235-251.

Reyment R.A., 1993. Ornamental and shape variation in Hemicytherura fulva McKenzie, Reyment and Reyment (Ostracoda; Eocene, Australia). Rev. Esp. Paleontol., 8, 125-131.

Reyment R.A., 1997. Evolution of shape in Oligocene and Miocene Notocarinovalva (Ostracoda, Crustacea): a multivariate statistical study. B. Math. Biol., 59, 63-87.

Reyment R.A. and Bookstein F.L., 1993. Infraspecific variability in shape in Neobuntonia airella: an exposition of geometric morphometry. In: McKenzie K.G. and Jones P.J. (eds.), Ostracoda in the Earth and Life Sciences, Balkema, Rotterdam, 291-314.
Reyment R.A., Bookstein F., McKenzie K.G. and Majoran S., 1988. Ecophenotypic variation in Mutilus pumilus (Ostracoda) from Australia, studied by canonical variate analysis and tensor biometrics. J. Micropalaentol., 7, 11-20.

Roberts J.H., Holmes J.A. and Swan A.R.H., 2002. Ecophenotypy in Limnocythere inopinata (Ostracoda) from the late Holocene of Kajemarum Oasis (north-eastern Nigeria). Palaeogeogr. Palaeoclimatol. Palaeoecol., 185, 41-52.

Rohlf F.J., 1990. Morphometrics. Annu. Rev. Ecol. Syst., 21, 299-316.

Rohlf F.J., 2001. TpsDig, digitize landmarks from image files, scanner, or video, version 2.17, Available online at: http//life.bio.sunysb.edu/morph/.

Rohlf F.J., 2003. TpsRelw, relative warps analysis, version 1.54, Available online at: http//life.bio.sunysb.edu/morph/.

Rohlf F.J., 2004. TpsUtil, tps file utility program, version 1.52, Available online at: http//life.bio.sunysb.edu/morph/.

Rohlf F.J. and Archie J.W., 1984. A comparison of Fourier methods for the description of wing shape in mosquitoes (Diptera, Culicidae). Syst. Zool., 33, 302-317.

Rohlf F.J. and Corti M., 2000. Use of two-block partial least-squares to study covariation in shape. Syst. Biol., 49, 740-753.

Rohlf F.J. and Slice D., 1990. Extensions of the Procrustes method for the optimal superimposition of landmarks. Syst. Zool., 39, 40-59.

Scheihing R., Labarca P., Cardenas L. and Nespolo R.F., 2011. Viability selection on body size in a non-marine ostracod. Hydrobiologia, 671, 193-203.

Schwalb A., Burns S.J., Cusminsky G.C., Kelts K. and Markgraf V., 2002. Assemblage diversity and isotopic signals of modern ostracods and host waters from Patagonia, Argentina. Palaeogeogr. Palaeoclimatol. Palaeoecol., 187, 323-339.

Slice D., Bookstein F.L., Marcus F.L. and Rohlf F.J., 1996. A glossary for geometric morphometrics. In: Marcus L.F., Corti M., Loy A., Naylor G.J.P. and Slice D.E. (eds.), Advances in Morphometrics, Plenum Press, New York, 531-551.

StatSoft Inc., 2010. STATISTICA (data analysis software system), version 10, Available online at: http//www.statsoft. com.

Turpen J.B. and Angell W.A., 1971. Aspects of molting and calcification in the ostracod Heterocypris. Biol. Bull., 140, 331-338.

Van der Meeren T., Verschuren D., Ito E. and Martens K., 2010. Morphometric techniques allow environmental reconstructions from low-diversity continental ostracod assemblages. J. Paleolimn., 44, 903-911.

Van Harten D., 1975. Size and environmental salinity in the euryhaline ostracod Cyprideis torosa (Jones, 1850), a biometrical study. Palaeogeogr. Palaeoclimatol. Palaeoecol., $17,35-48$.

Van Morkhoven F.P.C.M., 1962. Post-Palaeozoic Ostracoda. Their Morphology, Taxonomy, and Economic Use, Elsevier, Amsterdam, $204 \mathrm{p}$.

Whatley R. and Cusminsky G.C., 1999. Lacustrine Ostracoda and late Quaternary palaeoenviroments from the lake Cari-Laufquen region, Río Negro province, Argentina. Palaeogeogr. Palaeoclimatol. Palaeoecol., 151, 229-239. 
Whatley R. and Cusminsky G.C., 2000. Quaternary Lacustrine Ostracoda from northern Patagonia, a review. In: Gierlowski-Kordesch E.H. and Kelts K.R. (eds.), Late Basins through Space and Time, The American Association of Petroleum Geologists, Tulsa, 581-590.

Wrozyna C., Viehberg F., Cusminsky G.C. and Schwalb A., 2008. Soft parts dissection analysis and morphometric techniques on the genus Limnocythere from Chile and Argentina. In: IV Congreso Argentino de Limnología, San Carlos de Bariloche, Abstract p. 161.
Yin Y., Geiger W. and Martens K., 1999. Effects of genotype and environment on phenotypic variability in Limnocythere inopinata (Crustacea, Ostracoda). Hydrobiologia, 400, 85-114.

Zar J.H., 2010. Biostatistical Analysis (5th edn,), Pearson Prentice-Hall, New Jersey, 944 p.

Zelditch M.L., Swiderski D.L., Sheets H.D. and Fink W.L., 2004. Geometric Morphometrics for Biologists: a Primer, Elsevier, New York, 416 p. 